\title{
The rhizosphere revisited: root microbiomics
}

\author{
Peter A. H. M. Bakker*, Roeland L. Berendsen, Rogier F. Doornbos, Paul C. A. Wintermans \\ and Corné M. J. Pieterse
}

Plant-Microbe Interactions, Department of Biology, Faculty of Science, Utrecht University, Utrecht, Netherlands

\section{Edited by:}

Marcel Dicke, Wageningen University, Netherlands

\section{Reviewed by:}

Philippe Reymond, University of Lausanne, Switzerland

Anton Hartmann, Helmholtz Zentrum München; German Research Center for Environmental Health, Germany

\section{*Correspondence:}

Peter A. H. M. Bakker, Plant-Microbe Interactions, Department of Biology,

Faculty of Science, Utrecht University,

Padualaan 8, 3584 CH Utrecht,

Netherlands

e-mail:p.a.h.m.bakker@uu.nl
The rhizosphere was defined over 100 years ago as the zone around the root where microorganisms and processes important for plant growth and health are located. Recent studies show that the diversity of microorganisms associated with the root system is enormous. This rhizosphere microbiome extends the functional repertoire of the plant beyond imagination. The rhizosphere microbiome of Arabidopsis thaliana is currently being studied for the obvious reason that it allows the use of the extensive toolbox that comes with this model plant. Deciphering plant traits that drive selection and activities of the microbiome is now a major challenge in which Arabidopsis will undoubtedly be a major research object. Here we review recent microbiome studies and discuss future research directions and applicability of the generated knowledge.

Keywords: plant roots, microbial communities, extended phenotype, Arabidopsis thaliana, Pseudomonas spp

\section{INTRODUCTION}

Ever since Lorenz Hiltner, more than a century ago, defined the rhizosphere as the soil compartment influenced by plant roots (Hiltner, 1904; Hartmann et al., 2008), this hotspot for microbial interactions and activities has received ample attention from scientists in different disciplines. Also the above ground plant surface, the so-called phyllosphere, harbors microbial communities that have more recently been studied in detail (Vorholt, 2012). The microbial activity in the rhizosphere is essential for plant functioning as it assists the plant in nutrient uptake and offers protection against pathogen attack (Berendsen et al., 2012). Microbiological studies in the soil environment are hampered by the fact that the largest proportion of soil bacteria as yet cannot be cultured (Amann et al., 1995; Kent and Triplett, 2002; Doornbos et al., 2012). However, developments in metagenomics provide a more complete picture of the rhizosphere microbiome (Leveau, 2007; Sorensen et al., 2009; Hirsch and Mauchline, 2012). Thus the microbial players in the rhizosphere are on their way to be exposed and, perhaps more importantly, transcriptomic studies of the microbiome have been initiated to reveal microbial activities in complex environments (Urich et al., 2008; Gosalbes et al., 2012; Jansson et al., 2012). Unraveling processes that drive selection and activities of the rhizosphere microbiome will open up new avenues to manipulate crop health and yield. In this paper, we review and discuss recent developments in rhizosphere microbiome studies.

\section{THE RHIZOSPHERE EFFECT}

Compared to non-rooted bulk soil, the soil compartment directly around the plant root contains much larger populations of microorganisms (Foster et al., 1983). The increased microbial numbers and activities in the rhizosphere are due to the release of large amounts of organic carbon by the plant roots (Walker et al., 2003; Bais et al., 2006; Hartmann et al., 2009). In their extensive review, Jones et al. (2009) describe loss of root cap and border cells, insoluble mucilage, soluble root exudates, volatile organic carbon, flow of carbon to root associated symbionts, and death and lysis of root cells as the major processes of rhizodeposition. Soil microorganisms are chemotactically attracted to the plant root exudates, after which they proliferate in this carbon rich environment (Lugtenberg and Kamilova, 2009). Carbon limitation could be demonstrated in bulk soil but not in the rhizosphere using Pseudomonas fluorescens strains carrying carbon-limitation reporter systems (Van Overbeek et al., 1997; Koch et al., 2001). Given the fact that plant root exudates differ between plant species (Rovira, 1969), differences in rhizosphere microbiomes of different plant species are to be expected. Indeed plant-specific microbial communities could be isolated from roots in studies comparing, for example, wheat, ryegrass, bentgrass, and clover (Grayston et al., 1998), or wheat and canola (Germida et al., 1998). Also within a specific bacterial group like fluorescent Pseudomonas spp., plant species-specific rhizosphere populations could be isolated (Glandorf et al., 1993; Lemanceau et al., 1995). More recent studies, in which the rhizosphere microbiomes were characterized based on direct extraction of total community DNA, also provide strong evidence for plant species-specific microbiomes (Miethling et al., 2000; Smalla et al., 2001; Kirk et al., 2005; Inceoglu et al., 2013). The roots of wheat, maize, rape, and barrel clover were shown to carry different bacterial communities as a consequence of assimilation of root exudates (Haichar et al., 2008). Bacterial community structures in field grown potato rhizospheres were affected by the growth stage of the plant (Inceoglu et al., 2013). Also at the genotype level within a plant species, specificity of the rhizosphere microbiome has been described (Micallef et al., 2009a,b; Weinert et al., 2011). Micallef et al. (2009b) used A. thaliana and showed that the rhizosphere of this model plant mediates a significant change in the bacterial community relative to the bulk soil. To illustrate the rhizosphere effect we compared rhizosphere bacterial 
communities of tobacco and $A$. thaliana grown on a potting and a clay soil. In Figure 1A total bacterial counts on 1/10 strength tryptic soy agar (TSA) and counts of fluorescent pseudomonads on King's medium B agar (KB) in bulk soil and in the rhizospheres of A. thaliana Col-0 and tobacco are presented. The rhizosphere effect is exemplified by the observation that numbers in the rhizosphere are about 10- to 100-fold higher compared to the numbers in bulk soil for both plant species. In Figures 1B,C, Pseudomonasspecific denaturing gradient gel electrophoresis (DGGE) profiles are shown and compared in a redundancy analysis. For both tobacco and A. thaliana, rhizosphere Pseudomonas communities are different from those in the bulk soil, and the communities differ between the plant species. In two recent papers the $A$. thaliana root microbiome has been described in detail using pyrosequencing of 16S rRNA gene amplicons (Bulgarelli et al., 2012; Lundberg et al., 2012). Whereas differences between bacterial communities in bulk soil and the rhizosphere were observed in these studies, their focus was on the endophytic compartment. Inside the root, the microbiome clearly differed from the bulk soil and was enriched in Actinobacteria and Proteobacteria (Bulgarelli et al., 2012; Lundberg et al., 2012).

\section{RECRUITMENT OF THE RHIZOSPHERE MICROBIOME}

The rhizosphere bacterial community is recruited from the main reservoir of microorganisms present in soil (Normander and Prosser, 2000; De Ridder-Duine et al., 2005; Berg and Smalla, 2009). Thus the soil is an important factor in shaping the rhizosphere microbiome (Garbeva et al., 2008; Lundberg et al.,

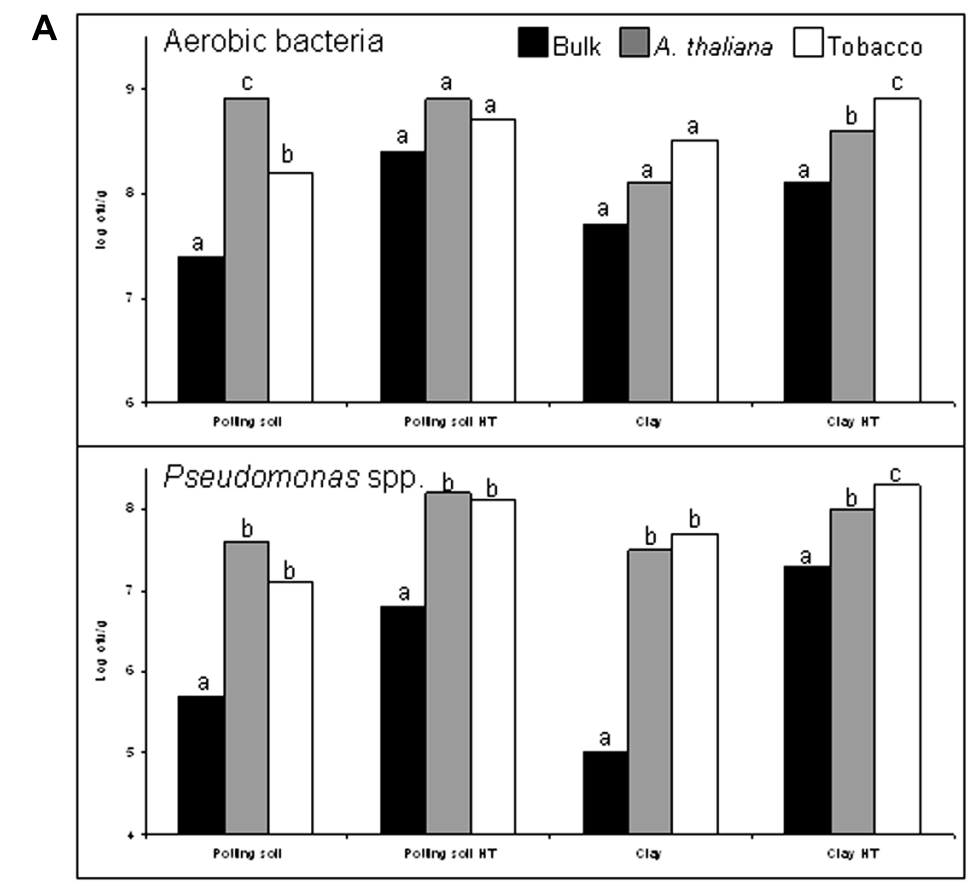

B

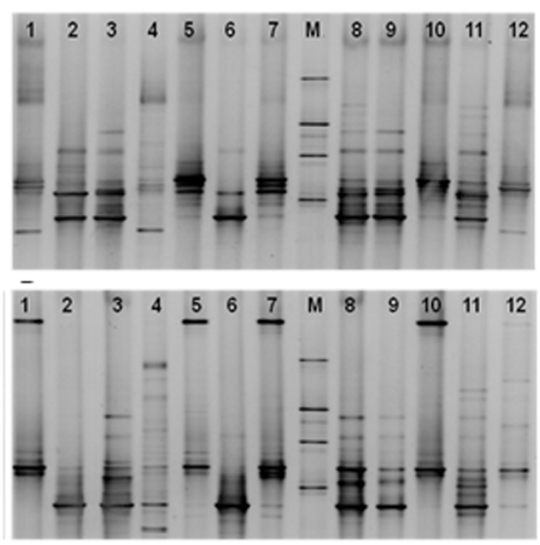

C
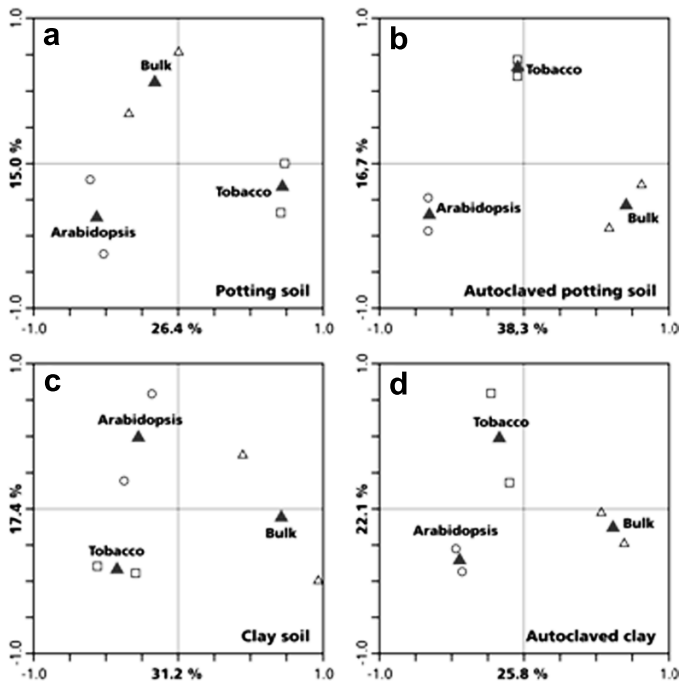

FIGURE 1 | (A) Numbers (log $\mathrm{cfu}^{-1}$ ) of culturable aerobic bacteria and Pseudomonas spp. in bulk (black bars) and rhizosphere soil of Arabidopsis (gray bars) and Tobacco (white bars). Plants were grown for 7 weeks on a potting soil-sand mixture or a clay soil, which were either untreated or autoclaved twice heat treatment $(\mathrm{HT})$ before planting. Different letters indicate significant differences within each soil type. (B) Denaturing gradient gel electrophoresis (DGGE) profile showing the Pseudomonas spp. community structure from bulk soils (top gel: potting soil; bottom gel: clay soil), and the rhizospheres of Arabidopsis and tobacco grown on these soils. $\mathrm{M}$, reference marker; lanes 1 and 10, Arabidopsis rhizosphere grown on non-autoclaved soil; lanes 2 and 6, autoclaved bulk soil; lanes 3 and 9, tobacco rhizosphere grown on autoclaved soil; lanes 4 and 12, non-autoclaved bulk soil; lanes 5 and 7, tobacco rhizosphere grown on non-autoclaved soil; lanes 8 and 11, Arabidopsis rhizosphere grown on non-autoclaved soil. (C) Ordination biplot generated by redundancy analysis (RDA) of Pseudomonas-specific DGGE fingerprints of bulk soil and the rhizospheres of Arabidopsis and tobacco grown on (a) potting soil-sand mixture; (b) autoclaved potting soil-sand mixture; (c) clay soil; (d) autoclaved clay soil. Open triangles, bulk; open circles, Arabidopsis rhizosphere; open squares, tobacco rhizosphere; gray triangles, centroid position of variables. 
2012). As described in the previous section, plant genotype is also a driving force for the selection of specific elements from the bulk soil microbial community. Furthermore, when under attack, plants seem to actively select specific elements of their bacterial rhizosphere microflora. This is most clearly observed in so-called disease suppressive soils, in which disease will not develop despite the presence of a virulent pathogen and a susceptible plant. Disease suppressiveness is due to microbial activity and usually needs an outbreak of disease to develop (Mazzola, 2002). A well-studied example is take-all decline (TAD), which develops in continuous wheat cultures after a severe outbreak of the take-all disease caused by Gaeumannomyces graminis var. tritici (Weller etal., 2002). Heat treatment abolishes suppressiveness and the suppressiveness of TAD soil is transferable to a disease conducive soil by mixing small quantities of decline soil through conducive soil. Under continuous wheat cropping, a specific group of fluorescent pseudomonads that produce 2,4diacetylphloroglucinol (DAPG) is enriched in the rhizosphere and these bacteria appear to be responsible for TAD (Raaijmakers and Weller, 1998). Additional bacterial taxa that may be involved in TAD have more recently been identified using 16S rRNAbased techniques (Sanguin et al., 2009; Schreiner et al., 2010). The specific selection of plant protecting bacteria in the rhizosphere under pathogen attack is supported by a recent study of Mavrodi et al. (2012). They observed that under irrigation the wheat rhizosphere recruits DAPG producing pseudomonads, whereas under dry conditions phenazine producing pseudomonads are recruited. Under irrigated conditions G. graminis var. tritici is the major soil borne pathogen of wheat, whereas under dry conditions Rhizoctonia solani is the main problem. Strikingly G. graminis var. tritici is more sensitive to DAPG, whereas $R$. solani is more sensitive to phenazines. Thus, under conditions that favor a specific pathogen, antagonists that are most effective against this pathogen are selected by the plant. Also for other disease suppressive soils specific elements of the microbiome have been identified that are associated with suppressiveness. In a Fusarium wilt suppressive soil the production of redox-active phenazines by fluorescent pseudomonads and competition for carbon by non-pathogenic Fusarium oxysporum have a synergistic effect that may establish suppressiveness (Mazurier et al., 2009). In a soil suppressive to potato common scab a microbial consortium that is associated with suppressiveness was identified (Rosenzweig et al., 2012). For a soil suppressive to black root rot of tobacco, caused by Thielaviopsis basicola, several bacterial taxa, including Pseudomonas, Azospirillum, Gluconacetobacter, Burkholderia, Comamonas, and Sphingomonadaceae, were shown to be more prevalent in the suppressive than in the conducive soil (Kyselkova et al., 2009). To identify bacteria involved in soil suppressiveness against $R$. solani, Mendes et al. (2011) used PhyloChip analysis, which allows simultaneous detection of $\sim 60,000$ bacterial and archaeal operational taxonomic units (OTUs). Over 33,000 OTUs were detected in the rhizospheres of sugar beet grown in $R$. solani suppressive and conducive soil. Taxa that were more abundant in suppressive soil and in a mixture of conducive soil with $10 \%$ suppressive soil than in conducive soil, but also more abundant in suppressive soil amended with $R$. solani than in suppressive soil without the pathogen, were identified. Seventeen taxa belonging to the $\beta$-proteobacteria, $\gamma$ proteobacteria, and the firmicutes were closely associated with disease suppressiveness (Mendes et al., 2011). In all disease suppressive soils mentioned here, consortia of antagonistic microorganisms seem to be recruited by the rhizosphere under pathogen attack.

Not only attack by soil borne pathogens results in the recruitment of beneficial microbes in the rhizosphere. Foliar feeding of aphids on pepper plants reduced disease development caused by the bacterial pathogen Xanthomonas axonopodis pv. vesicatoria (Lee et al., 2012). Aphid infestation resulted in increased population densities of the plant beneficial Bacillus subtilis, whereas it reduced rhizosphere populations of plant pathogenic Ralstonia solanacearum. Similar results were found for whitefly infestation of pepper plants, leading to increased resistance to pathogens and to changes in the rhizosphere microbiome (Yang et al., 2011). In the aphid and whitefly systems it would be interesting to investigate possible recruitment of rhizobacteria that produce insecticidal toxins, a feature of certain rhizosphere pseudomonads that was recently reported (Pechy-Tarr et al., 2013; Ruffner et al., 2013) A. thaliana plants exposed to methyl jasmonate showed a shift in their bacterial rhizosphere microbiome, including taxa that are associated with disease suppression, based on 16S rRNA gene amplicon pyrosequencing (Carvalhais et al., 2013). However, in a study by Doornbos et al. (2011), leaf application of jasmonic acid did not significantly affect the rhizosphere bacterial community of $A$. thaliana, based on DGGE analysis of $16 \mathrm{~S}$ rRNA gene amplicons. Rudrappa et al. (2008) showed that A. thaliana plants infected by the bacterial leaf pathogen $P$. syringae $\mathrm{pv}$. tomato, secrete elevated levels of malic acid in the rhizosphere. Malic acid stimulates binding to roots and biofilm formation on roots by Bacillus subtilis strain FB17, a beneficial microbe that can induce systemic resistance against diseases. Thus the plant benefits from protection against disease by the bacteria and in turn provides the bacteria with a more favorable environment. The recruitment of FB17 was recently shown to be mediated by root responses triggered by pathogen-derived microbe-associated molecular patterns in the leaves. Early suppression of defense genes by FB17 was postulated to facilitate colonization of this Bacillus subtilis strain on A. thaliana roots (Lakshmanan et al., 2012). Induced systemic resistance by $P$. putida KT2440 in A. thaliana is related to as yet unknown compounds in the root exudate that are modulated by the bacterium (Matilla et al., 2010). Thus not only pathogenic and symbiotic microorganisms seem to modulate host immunity to their own benefit, but also plant beneficial microorganisms seem to use this strategy (Zamioudis and Pieterse, 2012).

Drought stress is also a shaping factor for the rhizosphere microbiome. Drought-sensitive pepper plants that were grown under desert farming selected for a root microbiome that was enriched for bacteria that can increase photosynthesis and plant biomass production under drought stress (Marasco et al., 2012). Soil nitrogen availability influenced rhizosphere microbial communities of Medicago truncatula only in the presence of the plant, and it was suggested that the adaptive strategy of the plant to environmental constraints is a major factor in shaping the rhizosphere microbiome (Zancarini et al., 2012). 
Root exudates play an important role in shaping the rhizosphere microbiome. In the rhizosphere of maize, exudation of the benzoxazinone DIMBOA (2,4-dihydroxy-7-methoxy-1,4benzoxazin-3-one) resulted in increased population densities of a $P$. putida strain with plant beneficial characteristics (Neal et al., 2012). In A. thaliana, active exudation of phytochemicals mediated by ABC (ATP-binding cassette) transporters was demonstrated (Badri et al., 2012). In the absence of the plant, blends of collected $A$. thaliana root exudates modulated the soil microbiome. Phenolic compounds in the root exudates were suggested to act as specific substrates and signals for soil bacteria (Badri et al., 2013). Plant age affects rhizosphere bacterial communities of A. thaliana, suggested to be due to changes in root exudation (Micallef et al., 2009a). In an elegant study by Chaparro et al. (2013), combining metatranscriptomics and metabolomics, a strong correlation was observed between compounds released from the roots at different stages of plant development and the expression of microbial genes involved in metabolism of specific compounds.

Overall, evidence is accumulating that plants shape their rhizosphere microbiome to their own benefit, making sophisticated use of the functional repertoire of the microbiome.

\section{ACTIVATION OF MICROBIOME FUNCTIONS}

Next to recruitment of specific soil microbes into the rhizosphere microbiome, plant roots also influence specific functions of the microbiome. Quorum sensing, regulation of microbial gene expression in response to cell density, is an important mechanism to regulate microbial activities. Such activities include antibiotic production, biofilm formation, conjugation, motility, symbiosis, and virulence (Miller and Bassler, 2001). This regulatory mechanism is not only important within a bacterial population but also between bacterial populations (Pierson and Pierson, 2007; Hosni et al., 2011). Interkingdom communication based on quorum sensing signaling molecules, $\mathrm{N}$-acyl homoserine lactone (AHL) signals, has also been reported. Proteome analysis revealed that $M$. truncatula responds significantly to AHLs from both symbiotic and pathogenic bacteria (Mathesius et al., 2003). AHL signal molecules produced by Serratia liquefaciens and $P$. putida in the rhizosphere of tomato, protected the tomato plants against the fungal leaf pathogen Alternaria alternata, through the induction of systemic resistance (Schuhegger et al., 2006). Similarly, growth and disease resistance of $A$. thaliana are modulated by AHLs (Von Rad et al., 2008; Schikora et al., 2011; Liu et al., 2012; Schenk et al., 2012). Interkingdom communication can also involve effects of eukaryotes on bacterial gene expression. Plants can effectively interfere with quorum sensing in bacteria by producing so called AHL mimics (Teplitski et al., 2000; Gao et al., 2003). Thus there seems to be a plant-mediated fine tuning of bacterial gene expression in the rhizosphere. Microarray-based transcriptomic profiling of specific bacteria in response to root exudates of axenically grown plants has been used to identify genes in Pseudomonas (Mark et al., 2005) and Bacillus amyloliquefaciens (Fan et al., 2012) that are involved in plant microbe interactions. Using a similar approach, effects of phosphate availability on transcriptional responses of Pseudomonas in the rhizosphere of Lolium perenne was investigated (Zysko et al., 2012). All these studies show that there is a significant impact of root exudates on bacterial gene expression. The studies by Okubara and Bonsall (2008) and Kwak et al. (2012) focused on effects of host cultivar on the production of DAPG by fluorescent pseudomonads. The production of this antifungal metabolite, that plays a central role in TAD, depends on the genotypes of both the plant and the bacterial strain involved in the interaction. Effects of pathogen infection on gene expression and functional diversity has been the focus of several studies. Infection of wheat roots by G. graminis var. tritici changed gene expression of P. fluorescens Pf29Arp (Barret et al., 2009). Strain Pf29Arp was suggested to show an adaptive response to the so called pathorhizosphere of necrotic roots. In the rhizosphere of strawberry, infection with Verticillium dahliae increased hydrogen cyanide (HCN) biosynthesis gene expression in Pseudomonas sp. LBUM300 (DeCoste et al., 2010). HCN production by beneficial rhizobacteria has been suggested as a mechanism of biological control, and thus this study suggests that upon root pathogen attack such biocontrol activity is stimulated. Even stronger evidence that suggests up-regulation of antifungal activity upon pathogen attack comes from an elegant study by Jousset et al. (2011). They demonstrated in a split root system that infection of barley roots with Pythium ultimum on one side of the system, enhanced phlA gene expression, required for DAPG production, in $P$. fluorescens CHA0 that colonized the other side of the root system. Root exudation of fumaric acid, $p$-coumaric acid and vanillic acid was increased in Pythium infected plants and these phenolic acids increase phlA gene expression in a dose-dependent manner (Jousset et al., 2011). Thus plants seem to respond to pathogen infection by systemic signaling leading to enhanced biocontrol activity in the microbiome.

\section{PERSPECTIVE}

Exciting new insights in interkingdom signaling in the rhizosphere and the resulting effects on plant performance have emerged during the last decade. A. thaliana has been the model system of choice in several recent studies (Doornbos et al., 2011; Schwachtje et al., 2011; Bulgarelli et al., 2012; Lundberg et al., 2012; Van de Mortel etal., 2012) because a large number of accessions and well characterized mutants are readily available, and transcriptomic and metabolomic analyses are standard procedure for this plant species. Revealing the composition of the microbiome and unraveling the metatranscriptome will certainly help to shed light on the very dark rhizosphere environment. However, the rhizosphere is a dynamic environment in which the microbiome will rapidly evolve in space and time. Obviously, to date many rhizosphere metagenomic studies have focused on a single or a few time points and most studies do not take spatial dynamics into account. Metabolic profiling of living microbial colonies facilitates studying spatiotemporal dynamics of metabolite production in microbial communities (Moree et al., 2012; Watrous et al., 2012). The nanospray desorption electrospray ionization (nano-DESI) mass spectrometry technology used in these studies allows for direct sampling from plant surfaces (Traxler and Kolter, 2012) and is thus a promising development for rhizosphere studies. Given the rapid technological developments, the editors of the classic book "Plant roots: the hidden half" (Eshel and Beeckman, 2013), may want to look for a new title for the next edition. 


\section{REFERENCES}

Amann, R. I., Ludwig, W., and Schleifer, K. H. (1995). Phylogenetic identification and in situ detection of individual microbial cells without cultivation. Microbiol. Rev. 59, 143-169.

Badri, D. V., Chaparro, J. M., Manter, D. K., Martinoia, E., and Vivanco, J. M. (2012). Influence of ATP-binding cassette transporters in root exudation of phytoalexins, signals, and in disease resistance. Front. Plant Sci. 3:149. doi: 10.3389/fpls.2012.00149

Badri, D. V., Chaparro, J. H., Zhang, R., Shen, Q., and Vivanco, J. M. (2013). Application of natural blends of phytochemicals derived from the root exudates of Arabidopsis to the soil reveal that phenolicrelated compounds predominantly modulate the soil microbiome. $J$ Biol. Chem. 288, 4502-4512. doi: 10.1074/jbc.M112.433300

Bais, H. P., Weir, T. L., Perry, L. G., Gilroy, S., and Vivanco, J. M (2006). The role of root exudates in rhizosphere interactions with plants and other organisms. Annu. Rev. Plant Biol. 57, 233-266. doi 10.1146/annurev.arplant.57.032905. 105159

Barret, M., Frey-Klett, P., GuillermErckelboudt, A. V., Boutin, M. Guernec, G., and Sarniguet, A (2009). Effect of wheat roots infected with the pathogenic fungus Gaeumannomyces graminis var. tritici on gene expression of the biocontrol bacterium Pseudomonas fluorescens Pf29Arp. Mol. Plant Microbe Interact. 22, 1611-1623. doi: 10.1094/MPMI22-12-1611

Berendsen, R. L., Pieterse, C. M. J., and Bakker, P. A. H. M. (2012). The rhizosphere microbiome and plant health. Trends Plant Sci. 17, 478-486. doi: 10.1016/j.tplants.2012.04.001

Berg, G., and Smalla, K. (2009). Plant species and soil type cooperatively shape the structure and function of microbial communities in the rhizosphere. FEMS Microbiol. Ecol. 68, 1-13. doi: 10.1111/j.15746941.2009.00654.x

Bulgarelli, D., Rott, M., Schlaeppi, K., Ver Loren van Themaat, E., Ahmadinejad, N., Assenza, F. et al. (2012). Revealing structure and assembly cues for Arabidopsis root-inhabiting bacterial microbiota. Nature 488, 91-95. doi: 10.1038/nature11336

Carvalhais, L. C., Dennis, P. G., Badri, D. V., Tyson, G. W., Vivanco, J. M., and Schenk, P. M. (2013). Activation of the jasmonic acid plant defence pathway alters the composition of rhizosphere bacterial communities. PLOS ONE 8:e56457. doi: 10.1371/journal.pone.0056457

Chaparro, J. M., Badri, D. V., Bakker M. G., Sugiyama, A., Manter, D. K., and Vivanco, J. M. (2013). Root exudation of phytochemicals in Arabidopsis follows specific patterns that are developmentally programmed and correlate with soil microbial functions. PLOS ONE 8:e55731. doi: 10.1371/journal.pone. 0055731

DeCoste, N. J., Gadkar, V. J., and Filion, M. (2010). Verticillium dahliae alters Pseudomonas spp. populations and $\mathrm{HCN}$ gene expression in the rhizosphere of strawberry. Can. J. Microbiol. 56, 906-915. doi: 10.1139/ W10-080

De Ridder-Duine, A. S., Kowalchuk, G. A., Klein Gunnewiek, P. J. A., Smant, W., Van Veen, J. A., and De Boer, W. (2005). Rhizosphere bacterial community composition in natural stands of Carex arenaria (sand sedge) is determined by bulk soil community composition. Soil Biol. Biochem. 37, 349-357. doi: 10.1016/j.soilbio.2004.08.005

Doornbos, R. F., Geraats, B. P. J., Kuramae, E. E., Van Loon, L. C., and Bakker, P. A. H. M. (2011). Effects of jasmonic acid, ethylene, and salicylic acid signaling on the rhizosphere bacterial community of Arabidopsis thaliana. Mol. Plant Microbe Interact. 24, 395-407. doi: 10.1094/MPMI-0510-0115

Doornbos, R. F., Van Loon, L. C., and Bakker, P. A. H. M. (2012). Impact of root exudates and plant defense signaling on bacterial communities in the rhizosphere. Agron. Sustain. Dev. 32, 227-243. doi: 10.1007/s13593011-0028-y

Eshel, A., and Beeckman, T. (2013) Plant Roots: The Hidden Half, 4th Edn. Boca Raton, FL: CRC Press.

Fan, B., Cravalhais, L. C., Becker, A. Fedoseyenko, D., Von Wiren, N., and Borriss, R. (2012). Transcriptomic profiling of Bacillus amyloliquefaciens FZB42 in response to maize root exudates. BMC Microbiol. 12:116. doi: 10.1186/1471-2180-12-116

Foster, R. C., Rovira, A. D., and Cock, T. W. (1983). Ultrastructure of the Root-Soil Interface. St. Paul, MN: The American Phytopathological Society.

Gao, M., Teplitski, M., Robinson, J. B. and Bauer, D. W. (2003). Production of substances by Medicago truncatula that affect bacterial quorum sensing. Mol. Plant Microbe Interact. 16, 827-834. doi: 10.1094/MPMI.2003. 16.9.827
Garbeva, P. V., Van Elsas, J. D., and Van Veen, J. A. (2008). Rhizosphere microbial community and its response to plant species and soil history. Plant Soil 302, 19-32. doi: 10.1007/s11104-007-9432-0

Germida, J. J., Siciliano, S. D., De Freitas, J. R., and Seib, A. M. (1998). Diversity of root-associated bacteria associated with field-grown canola (Brassica napus L.) and wheat (Triticum aestivum L.). FEMS Microbiol. Ecol. 26, 43-50. doi: 10.1111/j.15746941.1998.tb01560.x

Glandorf, D. C. M., Peters, L. G. L., Van der Sluis, I., Bakker, P. A. H. M., and Schippers, B. (1993). Crop specificity of rhizosphere pseudomonads and the involvement of root agglutinins. Soil Biol. Biochem. 25, 981-989. doi: 10.1016/0038-0717(93)90144-Z

Gosalbes, M. J., Abellan, J. J., Durban, A., Perez-Cobas, A. E., Latorre, A., and Moya, A. (2012). Metagenomics of human microbiome: beyond $16 \mathrm{~s}$ rDNA. Clin. Microbiol. Infect. Dis 18, 47-49. doi: 10.1111/j.14690691.2012.03865.x

Grayston, S. J., Wang, S., Campbell, C. D., and Edwards, A. C (1998). Selective influence of plant species on microbial diversity in the rhizosphere. Soil Biol. Biochem. 30, 369-378. doi: 10.1016/S00380717(97)00124-7

Haichar, F. Z., Marol, C., Berge, O., Rangel-Castro, J. I., Prosser J. I., Balesdent, J., et al. (2008). Plant host habitat and root exudates shape soil bacterial community structure. ISME J. 2, 1221-1230. doi: 10.1038/ismej.2008.80

Hartmann, A., Rothballer, M., and Schmid, M. (2008). Lorenz Hiltner, a pioneer in rhizosphere microbial ecology and soil bacteriology research. Plant Soil 312, 7-14. doi: 10.1007/s11104-007-9514-Z

Hartmann, A., Schmid, M., Van Tuinen, D., and Berg, G. (2009). Plant-driven selection of microbes. Plant Soil 321, 235-257. doi: 10.1007/s11104-0089814-y

Hiltner, L. (1904). Uber neuere Erfahrungen und Probleme auf dem Gebiete der Bodenbakteriologie unter besonderden berucksichtigung und Brache. Arb. Dtsch. Landwirtsch. Gesellschaft 98, 59-78.

Hirsch, P. R., and Mauchline, T. H. (2012). Who's who in the plant roo microbiome? Nat. Biotechnol. 30, 961-962. doi: 10.1038/nbt.2387

Hosni, T., Moretti, C., Devescovi, G., Suarez-Moreno, Z. R., Fatmi, M. B., Guarnaccia, C., et al. (2011). Sharing of quorum-sensing signals and role of interspecies communities in a bacterial plant disease. ISME J. 5, 1857-1870. doi: 10.1038/ismej.2011.65

Inceoglu, O., Van Overbeek, L. S., Salles, J. F., and Van Elsas, J. D. (2013). The normal operating range of bacterial communities in soil used for potato cropping. Appl. Environ. Microbiol. 79, 1160-1170. doi: 10.1128/AEM.02811-12

Jansson, J. K., Neufeld, J. D., Moran, M. A., and Gilbert, J. A. (2012). Omics for understanding microbial functional dynamics. Environ. Microbiol. 14, 1-3. doi: 10.1111/j.14622920.2011.02518.x

Jones, D. L., Nguyen, C., and Finlay, R. D. (2009). Carbon flow in the rhizosphere: carbon trading at the soilroot interface. Plant Soil 321, 5-33. doi: 10.1007/s11104-009-9925-0

Jousset, A., Rochat, L., Lanoue, A., Bonkowski, M., Keel, C., and Scheu, S. (2011). Plants respond to pathogen infection by enhancing the antifungal gene expression of root-associated bacteria. Mol. Plant Microbe Interact. 24, 352-358. doi: 10.1094/MPMI-09. 10-0208

Kent, A. D., and Triplett, E. W. (2002). Microbial communities and their interactions in soil and rhizosphere ecosystems. Annu. Rev. Microbiol. 56, 211-236. doi: 10.1146/annurev.micro.56.012302. 161120

Kirk, J. L., Klironomos, J. N., Lee, H., and Trevors, J. T. (2005). The effects of perennial ryegrass and alfalfa on microbial abundance and diversity in petroleum contaminated soil. Environ. Pollut. 133, 455-465. doi: 10.1016/j.envpol.2004.06.002

Koch, B., Worm, J., Jensen, L. E., Hojberg, O., and Nybroe, O. (2001). Carbon limitation induces os-dependent gene expression in Pseudomonas fluorescens in soil. Appl. Environ. Microbiol. 67, 33633370. doi: 10.1128/AEM.67.8.33633370.2001

Kwak, Y. S., Bonsall, R. F., Okubara, P. A., Paulitz, T. C., Thomashow, L. S., and Weller, D. M. (2012). Factors impacting the activity of 2,4-diacetylphloroglucinolproducing Pseudomonas fluorescens against take-all of wheat. Soil Biol. Biochem. 54, 48-56. doi: 10.1016/j.soilbio.2012.05.012

Kyselkova, M., Kopecky, J., Frapolli, M., Defago, G., Sagova-Mareckova, M., Grundmann, G. L., et al. (2009). Comparison of rhizobacterial community composition in soil suppressive or conducive to tobacco black root rot disease. ISME J. 3, 11271138. doi: 10.1038/ismej.2009.61 
Lakshmanan, V., Kitto, S. L., Caplan, J. L., Hsueh, Y. H., Kearns, D. B., Wu, Y. S., et al. (2012). Microbe-associated molecular patterns-triggered root responses mediate beneficial rhizobacterial recruitment in Arabidopsis. Plant Physiol. 160, 1642-1661. doi: 10.1104/pp.112.200386

Lee, B., Lee, S., and Ryu, M. R. (2012). Foliar aphid feeding recruits rhizosphere bacteria and primes plant immunity against pathogenic and non-pathogenic bacteria in pepper. Ann. Bot. 110, 281-290. doi: 10.1093/aob/mcs055

Lemanceau, P., Corberand, T., Gardan, L., Latour, X., Laguerre, G., Boeufgras, J.-M., et al. (1995). Effect of two plant species, flax (Linum usitatissimum L.) and tomato (Lycopersicon esculentum Mill.), on the diversity of soilborne populations of fluorescent pseudomonads. Appl. Environ. Microbiol. 61, 1004-1012.

Leveau, J. H. J. (2007). The magic and menace of metagenomics: prospects for the study of plant growthpromoting rhizobacteria. Eur. J. Plant Pathol. 119, 279-300. doi: 10.1007/s10658-007-9186-9

Liu, F., Bian, Z., Jia, Z., Zhao, Q., and Song, S. (2012). The GCR1 and GPA1 participate in promotion of Arabidopsis primary root elongation induced by $N$-acyl-homoserine lactones, the bacterial quorum-sensing signals. Mol. Plant Microbe Interact. 25, 677-683. doi: 10.1094/MPMI-1011-0274

Lugtenberg, B., and Kamilova, F. (2009). Plant-growth-promoting rhizobacteria. Annu. Rev. Microbiol. 63, 541-556. doi: 10.1146/annurev.micro.62.081307. 162918

Lundberg, D. S., Lebeis, S. L., Herrera Paredes, S., Yourstone, S., Gehring, J., Malfatti, S., et al. (2012). Defining the core Arabidopsis thaliana root microbiome. Nature 488, 86-90. doi: 10.1038 /nature 11237

Marasco, R., Rolli, E., Ettoumi, B., Vigani, G., Mapelli, F., Borin, S., et al. (2012). A drought resistancepromoting microbiome is selected by root system under desert farming. PLOS ONE 7:e48479. doi: 10.1371/journal.pone.0048479

Mark, G. L., Dow, J. M., Kiely, P. D., Higgings, H., Haynes, J., Baysse, C., et al. (2005). Transcriptome profiling of bacterial responses to root exudates identifies genes involved in microbeplant interactions. Proc. Natl. Acad. Sci. U.S.A. 102, 17454-17459. doi: 10.1073/pnas.0506407102

Mathesius, U., Mulders, S., Gao, M., Teplitski, M., Caetano-Anolles, G.,
Rolfe, B. G., et al. (2003). Extensive and specific responses of a eukaryote to bacterial quorum-sensing signals. Proc. Natl. Acad. Sc. U.S.A. 100, 1444 1449. doi: 10.1073/pnas.262672599

Matilla, M. A., Ramos, J. L., Bakker, P. A. H. M., Doornbos, R. F., Vivanco, J. M., Badri, D. V., et al. (2010). Pseudomonas putida KT2440 causes induced systemic resistance and changes in Arabidopsis root exudation. Environ. Microbiol. Rep. 2, 381-388. doi: 10.1111/j.17582229.2009.00091.x

Mavrodi, O. V., Mavrodi, D. V., Parejko, J. A., Thomashow, L. S., and Weller, D. M. (2012). Irrigation differentially impacts populations of indigenous antibioticproducing Pseudomonas spp. in the rhizosphere of wheat. Appl. Environ. Microbiol. 78, 3214-3220. doi: 10.1128/AEM.07968-11

Mazurier, S., Corberand, T. Lemanceau, P., and Raaijmakers, J. M. (2009). Phenazine antibiotics produced by fluorescent pseudomonads contribute to natural soil suppressiveness to Fusarium wilt. ISME J. 3, 977-991. doi: 10.1038/ismej. 2009.33

Mazzola, M. (2002). Mechanisms of natural soil suppressiveness to soilborne diseases. Antonie Van Leeuwenhoek 81, 557-564. doi 10.1023/A:1020557523557

Mendes, R., Kruijt, M., De Bruijn, I., Dekkers, E., Van der Voort, M., Schneider, J. H. M., et al. (2011) Deciphering the rhizosphere microbiome for disease-suppressive bacteria. Science 332, 1097-1100. doi: 10.1126/science. 1203980

Micallef, S. A., Channer, S., Shiaris, M. P., and Colon-Carmona, A. (2009a). Plant age and genotype impact the progression of bacterial community succession in the Arabidopsis rhizosphere. Plant Signal. Behav. 4, 777780. doi: $10.4161 /$ psb.4.8.9229

Micallef, S. A., Shiaris, M. P., and Colon-Carmona, A. (2009b). Influence of Arabidopsis thaliana accessions on rhizobacterial communities and natural variation in root exudates. J. Exp. Bot. 60, 1729-1742. doi: 10.1093/jxb/erp053

Miethling, R., Wieland, G., Backhaus, H., and Tebbe, C. C. (2000). Variation in microbial rhizosphere communities in response to crop species, soil origin, and inoculation with Sinorhizobium meliloti L33. Microb. Ecol. 40, 43-56. doi: 10.1007/s002480000021

Miller, M. B., and Bassler, B. L. (2001). Quorum sensing in bacteria. Annu. Rev. Microbiol. 55, 165-199. doi: 10.1146/annurev.micro.55.1.165
Moree, W. J., Phelan, V. V., Wu, C.-H., Bandeira, N., Cornett, D. S., Duggan, B. M., et al. (2012). Interkingdom metabolic transformations captured by microbial imaging mass spectrometry. Proc. Natl. Acad. Sci. U.S.A. 109 , 13811-13816. doi: 10.1073/pnas. 1206855109

Neal, A. L., Ahmad, S., GordonWeeks, R., and Ton, J. (2012). Benzoxazinoids in root exudates of maize attract Pseudomonas putida to the rhizosphere. PLoS ONE 7:e35498. doi: 10.1371/journal.pone. 0035498

Normander, B., and Prosser, J. I. (2000). Bacterial origin and community composition in the barley phytosphere as a function of habitat and presowing conditions. Appl. Environ. Microbiol. 66, 43724377. doi: 10.1128/AEM.66.10.43724377.2000

Okubara, P. A., and Bonsall, R. F. (2008). Accumulation of Pseudomonas derived 2,4-diacetylphloroglucinol on wheat seedling roots is influenced by host cultivar. Biol. Control 46, 322-331. doi: 10.1016/j.biocontrol.2008.03.013

Pechy-Tarr, M., Borel, N., Kupferschmied, P., Turner, V., Binggeli, O., Radovanovic, D., et al. (2013). Control and host-dependent activation of insect toxin expression in a rootassociated biocontrol pseudomonad. Environ. Microbiol. 15, 736-750. doi: 10.1111/1462-2920.12050

Pierson, L. S. III, and Pierson, E. A. (2007). Roles of diffusible signals in communication among plantassociated bacteria. Phytopathology 97, 227-232. doi: 10.1094/PHYTO 97-2-0227

Raaijmakers, J. M., and Weller, D. M. (1998). Natural plant protection by 2,4-diacetylphloroglucinolproducing Pseudomonas spp. in take-all decline soils. Mol. Plant Microbe Interact. 11, 144-152. doi: 10.1094/MPMI.1998.11.2.144

Rosenzweig, N., Tiedje, J. M., Quensen, J. F. III, Meng, Q., and $\mathrm{Hao}$, J. J. (2012). Microbial communities associated with potato common scab-suppressive soil determined by pyrosequencing analyses. Plant Dis. 96, 718-725. doi: 10.1094/PDIS-0711-0571

Rovira, A. D. (1969). Plant root exudates. Bot. Rev. 35, 17-34. doi: 10.1007/BF02859887

Rudrappa, T., Czymmek, K. J., Paré, P. W., and Bais, H. P. (2008). Root-secreted malic acid recruits beneficial soil bacteria. Plant Physiol. 148, 1547-1556. doi: $10.1104 /$ pp. 108.127613
Ruffner, B., Pechy-Tarr, M., Ryffel, F., Hoegger, P., Obrist, C., Rindlisbacher, A., et al. (2013). Oral insecticidal activity of plant-associated pseudomonads. Eviron. Microbiol. 15, 751-763. doi: 10.1111/j.14622920.2012.02884.x

Sanguin, H., Sarniguet, A., Gazengel, K., Moenne-Loccoz, Y., and Grundmann, G. L. (2009). Rhizosphere bacterial communities associated with disease suppressiveness stages of take-all decline in wheat monoculture. New Phytol. 184, 694707. doi: 10.1111/j.1469-8137.2009. 03010.x

Schenk, S. T., Stein, E., Kogel, K. H., and Schikora, A. (2012). Arabidopsis growth and defense are modulated by bacterial quorum sensing molecules. Plant Signal. Behav. 7, 178-181. doi: 10.4161/psb.18789

Schikora, A., Schenk, S. T., Stein, E., Molitor, A., Zuccaro, A., and Kogel, K. H. (2011). Nacyl-homoserine lactone confers resistance toward biotrophic and hemibiotrophic pathogens via altered activation of AtMPK6. Plant Physiol. 157, 1407-1418. doi: 10.1104/pp.111.180604

Schreiner, K., Hagn, A., Kyselkova, M., Moenne-Loccoz, Y., Welzl, G., Munch, J. C., et al. (2010). Comparison of barley succession and takeall disease as environmental factors shaping the rhizobacterial community during take-all decline. Appl. Environ. Microbiol. 76, 4703-4712. doi: 10.1128/AEM.00481-10

Schuhegger, R., Ihring, A., Gantner, S., Bahnweg, G., Knappe, C., Vogg, G., et al. (2006). Induction of systemic resistance in tomato by $N$-acyl-Lhomoserine lactone-producing rhizosphere bacteria. Plant Cell Environ. 29, 909-918. doi: 10.1111/j.13653040.2005.01471.x

Schwachtje, J., Karojet, S., Thormalen, I., Bernholz, C., Kunz, S., Brouwer, S., etal. (2011). A naturally associated rhizobacterium of Arabidopsis thaliana induces a starvation-like transcriptional response while promoting growth. PLoS ONE 6:e29382. doi: 10.1371/journal.pone.0029382

Smalla, K., Wieland, G., Buchner, A., Zock, A., Parzy, J., Kaiser, S., et al. (2001). Bulk and rhizosphere soil bacterial communities studied by denaturing gradient gel electrophoresis: plant-dependent enrichment and seasonal shifts revealed. Appl. Environ. Microbiol. 67, 47424751. doi: 10.1128/AEM.67.10.47424751.2001

Sorensen, J., Hauberg Nicolaisen, M., Ron, E., and Simonet, P. 
(2009). Molecular tools in rhizosphere microbiology - from single-cell to whole-community analysis. Plant Soil 321, 483-512. doi: 10.1007/s11104-009-9946-8

Teplitski, M., Robinson, J. B., and Bauer, W. D. (2000). Plants secrete substances that mimic bacterial $N$-acyl homoserine lactone signal activities and affect population density-dependent behaviors in associated bacteria. Mol. Plant Microbe Interact. 13, 637-648. doi: 10.1094/MPMI.2000. 13.6.637

Traxler, M. F., and Kolter, R. (2012). A massively spectacular view of the chemical lives of microbes. Proc. Natl. Acad. Sci. U.S.A. 109, 10128-10129. doi: 10.1073/pnas.1207725109

Urich, T., Lanzen, A., Qi, J., Huson, D. H., Schleper, C., and Schuster, S. C. (2008). Simultaneous assessment of soil microbial community structure and function through analysis of the meta-transcriptome. PLoS ONE 3:e2527. doi: 10.1371/journal.pone. 0002527

Van de Mortel, J. E., De Vos, R. C. H., Dekkers, E., Pineda, A., Guillod, L., Bouwmeester, K., etal. (2012). Metabolic and transcriptomic changes induced in Arabidopsis by the rhizobacterium Pseudomonas fluorescens SS101. Plant Physiol. 160, 2173-2188. doi: 10.1104/pp.112.207324
Van Overbeek, L. S., Van Elsas, J. D., and van Veen, J. A. (1997). Pseudomonas fluorescens Tn5-B20 mutant RA92 responds to carbon limitation in soil. FEMS Microbiol. Ecol. 24, 57-71. doi: 10.1016/S0168-6496(97)00045-7

Von Rad, U., Klein, I., Dobrev, P. I., Kottova, J., Zazimalova, E., Fekete, A., et al. (2008). Response of Arabidopsis thaliana to $N$-hexanoylDL-homoserine-lactone, a bacterial quorum sensing molecule produced in the rhizosphere. Planta 229, 73-85. doi: 10.1007/s00425-008-0811-4

Vorholt, J. A. (2012). Microbial life in the phyllosphere. Nat. Rev. Microbiol. 10, 828-840. doi: 10.1038/nrmicro2910

Walker, T. S., Bais, H. P., Grotewold, E., and Vivanco, J. M. (2003). Root exudation and rhizosphere biology. Plant Physiol. 132, 44-51. doi: 10.1104/pp.102.019661

Watrous, J., Roach, P., Alexandrov, T., Heath, B. S., Yang, J. Y., Kersten, R. D., et al. (2012). Mass spectral molecular networking of living microbial colonies. Proc. Natl. Acad. Sci. U.S.A. 109, E1743-E1752. doi: 10.1073/pnas.1203689109

Weinert, N., Piceno, Y., Ding, G. C., Meincke, R., Heuer, H., Berg, G., etal. (2011). PhyloChip hybridization uncovered an enormous bacterial diversity in the rhizosphere of different potato cultivars: many common and few cultivar-dependent taxa. FEMS Microbiol. Ecol. 75, 497-506. doi: 10.1111/j.1574-6941.2010.01025.x

Weller, D. M., Raaijmakers, J. M., McSpadden Gardener, B. B. and Thomashow, L. S. (2002). Microbial populations responsible for specific soil suppressiveness to plant pathogens. Annu. Rev. Phytopathol. 40, 309-348. doi: 10.1146/ annurev.phyto.40.030402.110010

Yang, J. W., Yi, H. S., Kim, H., Lee, B., Lee, S., Ghim, S. Y., etal. (2011). Whitefly infestation of pepper plants elicits defence responses against bacterial pathogens in leaves and roots and changes the below-ground microflora. J. Ecol. 99, 46-56. doi: 10.1111/j.1365 2745.2010.01756.x

Zamioudis, C., and Pieterse, C. M. J. (2012). Modulation of host immunity by beneficial microbes. Mol. Plant Microbe Interact. 25, 139-150. doi: 10.1094/MPMI-06-11-0179

Zancarini, A., Mougel, C., Voisin, A. S., Prudent, M., Salon, C., and Munier-Jolain, N. (2012). Soil nitrogen availability and plant genotype modify the nutrition strategies of $M$. truncatula and the associated rhizosphere microbial communities. PLoS ONE 7:e47096. doi: 10.1371/journal.pone.0047096

Zysko, A., Sanguin, H., Hayes, A., Wardleworth, L., Zeef, L. A. H. Sim, A., et al. (2012). Transcriptional response of Pseudomonas aeruginosa to a phosphate-deficient Lolium perenne rhizosphere. Plant Soil 359, 25-44. doi: 10.1007/s11104-0111060-Z

Conflict of Interest Statement: The authors declare that the research was conducted in the absence of any commercial or financial relationships that could be construed as a potential conflict of interest.

Received: 28 February 2013; paper pending published: 19 April 2013; accepted: 10 May 2013; published online: 30 May 2013.

Citation: Bakker PAHM, Berendsen RL, Doornbos RF, Wintermans PCA and Pieterse CMJ (2013) The rhizosphere revisited: root microbiomics. Front. Plant Sci. 4:165. doi: 10.3389/fpls.2013.00165 This article was submitted to Frontiers in Plant-Microbe Interaction, a specialty of Frontiers in Plant Science.

Copyright (c) 2013 Bakker, Berendsen, Doornbos, Wintermans and Pieterse. This is an open-access article distributed under the terms of the Creative Commons Attribution License, which permits use, distribution and reproduction in other forums, provided the original authors and source are credited and subject to any copyright notices concerning any thirdparty graphics etc. 